\title{
CHARACTERIZATION OF COMMUNITY STRUCTURE OF CULTURABLE ENDOPHYTIC FUNGI IN SWEET CHERRY COMPOSITE TREES AND THEIR GROWTH- RETARDING EFFECT AGAINST PATHOGENS
}

\author{
Neda Haddadderafshi, ${ }^{1}$ Tímea Borbála Pósa,,${ }^{1}$ Gábor Péter, ${ }^{4}$ László Gáspár, ${ }^{1}$ \\ Márta Ladányi, ${ }^{2}$ Károly Hrotkó, ${ }^{3}$ NoÉmi LuKÁCs ${ }^{1}$ * and Krisztián Halász ${ }^{1}$ \\ ${ }^{1}$ Szent István University, Faculty of Horticultural Science, Department of Plant Physiology and Plant \\ Biochemistry, Villányi út 29-43, 1118 Budapest, Hungary \\ ${ }^{2}$ Szent István University, Faculty of Horticultural Science, Department of Biometrics and Agricultural \\ Informatics, Villányi út 29-43, 1118 Budapest, Hungary \\ ${ }^{3}$ Szent István University, Faculty of Horticultural Science, Department of Floriculture and Dendrology, \\ Villányi út 29-43, 1118 Budapest, Hungary \\ ${ }^{4}$ Szent István University, Faculty of Food Science, National Collection of Agricultural and Industrial \\ Microorganisms, Somlói út 14-16, 1118 Budapest, Hungary
}

(Received: November 18, 2016; accepted: November 30, 2016)

\begin{abstract}
Endophytic fungi have the potential to protect their host plants in stress situations. Characterizing the ecology and complex interaction between these endophytes and their host plants is therefore of great practical importance, particularly in horticultural plants. Among horticultural plants, fruit trees form a special category because of their longevity and because they are composites of rootstock and scion, which often belong to different plant species. Here we present the first characterization of culturable endophytic fungal community of sweet cherry. Samples from the Hungarian cultivar 'Petrus' grafted on 11 different rootstocks were collected in autumn and in spring in a bearing orchard and the dependence of colonization rate and endophyte diversity on rootstock, organ and season was analysed. On the basis of their ITS sequences 26 fungal operational taxonomic units were identified at least down to the genus level. The dominant genus, comprising more than $50 \%$ of all isolates, was Alternaria, followed by different Fusarium and Epicoccum species. We observed some organ-specificity amongst endophytes, and organs showed more sizeable differences in colonization rates and endophyte diversity than rootstocks. Most dynamic endophyte populations, strongly influenced by environmental conditions and crop management, were observed in leaves. The potential of selected endophytes to confer protection against Monilinia laxa was also analysed and 7 isolates were found to inhibit the growth of this pathogen in vitro.
\end{abstract}

Keywords: Endophytic fungi - sequence-based identification - sweet cherry - rootstock - Monilinia

\section{INTRODUCTION}

Endophytes and among them, endophytic fungi, seem to be ubiquitous in plants and may play a major role in the productivity of the ecosystem as well as in nutrient cycling $[34,41]$. Endophyte infection is assumed to remain asymptomatic, although the host-endophyte interrelation is complex and may range from mutualism to antago-

*Corresponding author, e-mail address: Lukacs.Noemi@kertk.szie.hu 
nism depending on environmental conditions [1]. Evidently, fungal symbionts have a pivotal impact on plant survival and fitness and are probably able to induce augmented host tolerance to different kinds of stresses such as drought, salinity, heat shock and abiotic agents $[5,33]$. Moreover, endophytes may contribute to the host plant's defence against natural pathogens and may even protect the host from insect herbivores by indirect mechanisms [26]. Empirical evidence demonstrates that reciprocal cooperation between host and fungal symbiont is species-specific and strongly related to the phylogenetic diversity of both partners $[1,3,13]$.

Fungal endophytes are generally divided into two major groups based on their genotypic diversity and ecological functions as well as on the potential competency for localization within specific individual hosts or plant tissues. C-endophytes (clavicipitaceous) have been studied primarily in grasses. They usually infest the host plant as one dominant fungal isolate/genotype and are vertically transmitted from maternal plants to offspring via seed infection. They confer benefits to the host in a host-specific manner which also depends on environmental conditions. Non-clavicipitaceous (NC-) endophytes exhibit a remarkable diversity. They display less host-specificity and are divided into three subclasses according to their biodiversity and transmission route (vertical or horizontal).

The reciprocal interface between plant and endophytic fungi is based on an array of intricate factors which have yet to be investigated to improve the existing knowledge about the role of fungal endophytes in terrestrial ecosystems [4, 34]. Many existing studies demonstrate that endophytic fungi can exhibit various levels of host and tissue specificity, but may show temporal and spatial, i.e. environment-dependent, variations in terms of their abundance and community structure [2, 10, 12, 46]. Recent results suggest that genetic differences in a given host species can also shape the structure of endophyte communities, which may feedback to influence plant growth and fitness [25]. In addition, it has been shown that agrotechnology may also influence endophyte communities and organically managed farms have a higher frequency and higher taxon diversity than integrated production systems [15, 29].

However, very little is known about the distribution of fungal endophytes, the structure of their assemblages and their potential impact on plant-pathogen interaction in fruit trees which are usually grafted. Grafting is a common and continuously expanding practice in all fields of horticulture. Many horticultural plants are therefore composites of rootstock and scion, which can belong to two genetically different species. In addition, depending on climatic and agronomic requirements, scions of a given species are often combined with different rootstocks to obtain optimal growth and yields.

The present study was designed to characterize the fungal endophytes' diversity and the composition of their assemblage in the sweet cherry cultivar 'Petrus' grafted onto 8 different Prunus mahaleb rootstocks as well as onto wild $P$. avium and on the dwarfing rootstocks 'GiSelA 6' ( $P$. cerasus $\times P$. canescens) and 'Prob' ( $P$. fruticosa Pall. forma aucta Borb.). This is, to our knowledge, the first detailed analysis of fungal endophytes in sweet cherry. We isolated culturable endophytic fungi from roots, from $<1$ year old shoots and from leaves at 3 different sampling times and identified 
them on the basis of morphological features and by comparing their ITS sequences. In addition, we identified several fungal isolates which led to growth inhibition of the fungal pathogen, Monilinia laxa in dual culture in vitro. Preliminary results of one sampling time were published earlier [18]. Re-evaluated data from this publication are included in statistical analyses of the present paper for comparison.

\section{MATERIALS AND METHODS}

\section{Site conditions}

Plants were grown in the Research and Experimental Farm of Szent István University of Budapest. The station ( $19^{\circ} 03^{\prime} 01^{\prime \prime}$ LE and $\left.47^{\circ} 28^{\prime} 19^{\prime \prime} \mathrm{LN}\right)$ is located in Budapest, Central Hungary, $103 \mathrm{~m}$ above sea level. In terms of climate, the site belongs to the continental Great Hungarian Plane with a yearly average temperature of $11.3{ }^{\circ} \mathrm{C}$ and $2079 \mathrm{~h}$ of total sunshine. Average annual rainfall is about $550 \mathrm{~mm}$, falling mainly in May and June. The soil is light sandy. The experimental orchard was planted in 2004 at a spacing of $4 \times 2 \mathrm{~m}$. The sweet cherry cultivar 'Petrus' grafted on different rootstocks was planted in randomized plots; trees were trained to Hungarian spindle [22]. They began to bear in 2006, and reached their final height of 4.5-5 $\mathrm{m}$ in summer 2009 , when they were headed at 3.4-4.0 m. In the alleyway, the natural vegetation (grass and weed) was mown [23]. We collected samples in years 2008 and 2009. To protect trees from monilinia infection, fungicide treatment was carried out in AprilMay in both years. In 2009, the treatment took place 24 days before our second sampling. In addition to this, in August 2008 trees were sprayed twice with Dithan DG Neo-Tec against Blumeriella infection. No fungicide treatment was needed in summer 2009. Parallel to our work the photosynthetic activity, water household and mineral nutrition of the trees was also analysed $[17,21,23]$.

\section{Plant material and sample collection}

Root, shoot and leaf samples were collected form the Hungarian sweet cherry cultivar 'Petrus' grafted on 8 different $P$. mahaleb rootstocks, on $P$. avium, on 'GiSelA 6' (P. cerasus $\times$ P. canescens) or on 'Prob' (P. fruticosa Pall. forma aucta Borb.). Six of the P. mahaleb rootstocks, i.e. 'Erdi V', 'SL64', 'Egervar', 'Korponay', 'SM11/4' and 'CEMANY' were seedlings, while 'Bogdany' and 'Magyar' are clonally propagated. 'GiSelA6' and 'Prob' are dwarfing rootstocks [21]. Samples were taken from randomly selected trees in October 2008, May 2009 and in October 2009. In total 110 trees were sampled. The same individual plants were used for our study during all sampling periods, 2-2 samples were collected from each tree and organ. The sampled tissues were young roots of a length of $10 \mathrm{~cm}$ and a diameter of $\approx 2 \mathrm{~mm}$, fully differentiated leaves and the uppermost $10 \mathrm{~cm}$ of green or maximally one year old shoots. Samples were stored in plastic bags at $5{ }^{\circ} \mathrm{C}$ for $1-6$ hours. 


\section{Tissue preparation and single spore isolation of endophytic fungi}

Samples were thoroughly cleaned and then sterilized in $96 \%$ ethanol for $1 \mathrm{~min}$, in 3\% hypochlorite for $10 \mathrm{~min}$ and again in $96 \%$ ethanol for $1 \mathrm{~min}$. After washing twice with sterile distilled water roots and shoots were cut into $10 \mathrm{~mm}$ long pieces, leaves to discs of $\sim 10 \mathrm{~mm}$ diameter. Potato Dextrose Agar (PDA) and Malt Extract Agar (MEA) were used as pre-culturing media. 10 segments of each organ were transferred to PDA plates supplemented with $1 \mathrm{~g} / 1$ chloramphenicol. Plates were incubated at $22{ }^{\circ} \mathrm{C}$ and colonies were observed after 1-2 weeks. Single spore isolation of endophytic fungi was performed according to the method described by Choi et al. [8].

\section{Morphological characterization}

Cultures on both PDA and MEA media were assessed according to their morphology. Colony appearance, mycelium color and structure, shape of conidiomata, conidia and conidiophore (size, color, ornamentation, etc.) and conidiogenous cells were observed for morphological classification of isolated fungi.

\section{PCR amplification and sequencing of the ITS region}

Total DNA was extracted from fungal components by applying a modified CTAB method [9]. Amplification of total Internal Transcribed Spacer (ITS-1 + 5.8SRNA+ ITS-2) region was performed using fungal domain specific ITS1 and ITS4 primers [43]. Closely related reliable nucleotide sequences were searched by BLAST algorithm in GenBank. Identification was performed to the genus or species level.

\section{Data analysis}

Colonization rate was calculated as the total number of organ fragments infected by one or more endophytic fungus divided by the total number of fragments. Isolation rate was defined as the quotient of the total number of colonies isolated from an organ and the total number of explants from that organ. To analyse the potential rootstockdependence of the colonization rate, $\chi^{2}$ test was made which was followed by post hoc $z$ tests for pair-wise comparison applying the Bonferroni correction. Possible differences in number and diversity of fungal endophytes recovered from each rootstockscion combination at the three sampling times were also considered. Species richness (S) was calculated for diversity analysis. Shannon index (H), Shannon-Weaver index $\left(\mathrm{e}^{\mathrm{H}^{\prime}}\right)$ and Simpson's diversity index (1-D) were used to compare the diversity of endophyte species in the three examined organs and in different rootstocks by two-way ANOVA models. Normality of residuals and homogeneity of variances were checked by Kolmogorov-Smirnov's or Levene's tests, respectively $(p>0.05)$. Endophytic 
fungal colonies which could not be identified by morphological or molecular methods were omitted from calculations.

\section{Analysis of endophyte - pathogen antagonism by dual culture method}

A dual culture method was applied to assess the antagonism of endophytic fungi to Monilinia laxa Aderh. et Ruhl., a relevant fungal pathogen of sweet cherry. M. laxa was kindly provided by Géza Nagy (Department of Plant Pathology, Szent István University of Budapest, Hungary).

Inocula of the selected endophyte and the pathogen were aseptically planted 40 $\mathrm{mm}$ apart from each other on a Petri dish $(\mathrm{d}=90 \mathrm{~mm})$ containing $30 \mathrm{ml}$ fresh PDA medium. Inocula of the endophyte and the pathogen - placed separately on Petri dishes - were used as controls. All plates were incubated at $28^{\circ} \mathrm{C}$ for 15 days. Five replicates were used for each plate.

Daily horizontal growth was calculated from the average of daily growth from day 2-7 in the first, and from day 9-14 in the second week.

\section{RESULTS}

\section{Isolation and dynamics of culturable endophytic fungi in sweet cherry}

To identify culturable endophytic fungi living in cherry trees, samples were collected from roots, young shoots and from fully differentiated leaves of the sweet cherry cultivar 'Petrus' grafted on 11 different rootstocks ( 8 of them $P$. mahaleb). In three seasons (October 2008, May 2009 and October 2009) a total of 9823 tissue segments were examined: 3397 from roots, 3233 from young shoots and 3193 from leaves. Of these 1944 fungal endophytes grew out from root, 3427 from shoot and 1216 from leaf inocula. All in all we obtained 6587 fungal isolates. First we analysed the colonization and isolation rates in different organs (Fig. 1). The highest colonization rates were found in young shoots (in average $78.3 \%$ ), the lowest in leaves $(32.5 \%)$. The colonization rate of roots was $47.5 \%$ on average. Although we observed considerable differences between sampling times, we found no systematic season-dependent changes in roots. In contrast, colonization rates exhibited significant disparity in shoots and leaves between seasons and were lowest in May in all rootstock-scion combinations (Fig. 1). We observed an unusually high enhancement of colonization rates in all leaves in autumn 2009 (see Fig. 1). Since this may be connected to crop management, we would like to point out that trees were headed in summer 2009 and no fungicide treatment was applied thereafter (see in Material and Methods).

It is well known that rootstocks can influence physiological features, growth and productivity of a scion, therefore we wanted to find out whether such effects can be observed in colonization by endophytic fungi as well. Since we observed no obvious differences at first glance (Fig. 1), and pair-by-pair comparison revealed a very com- 

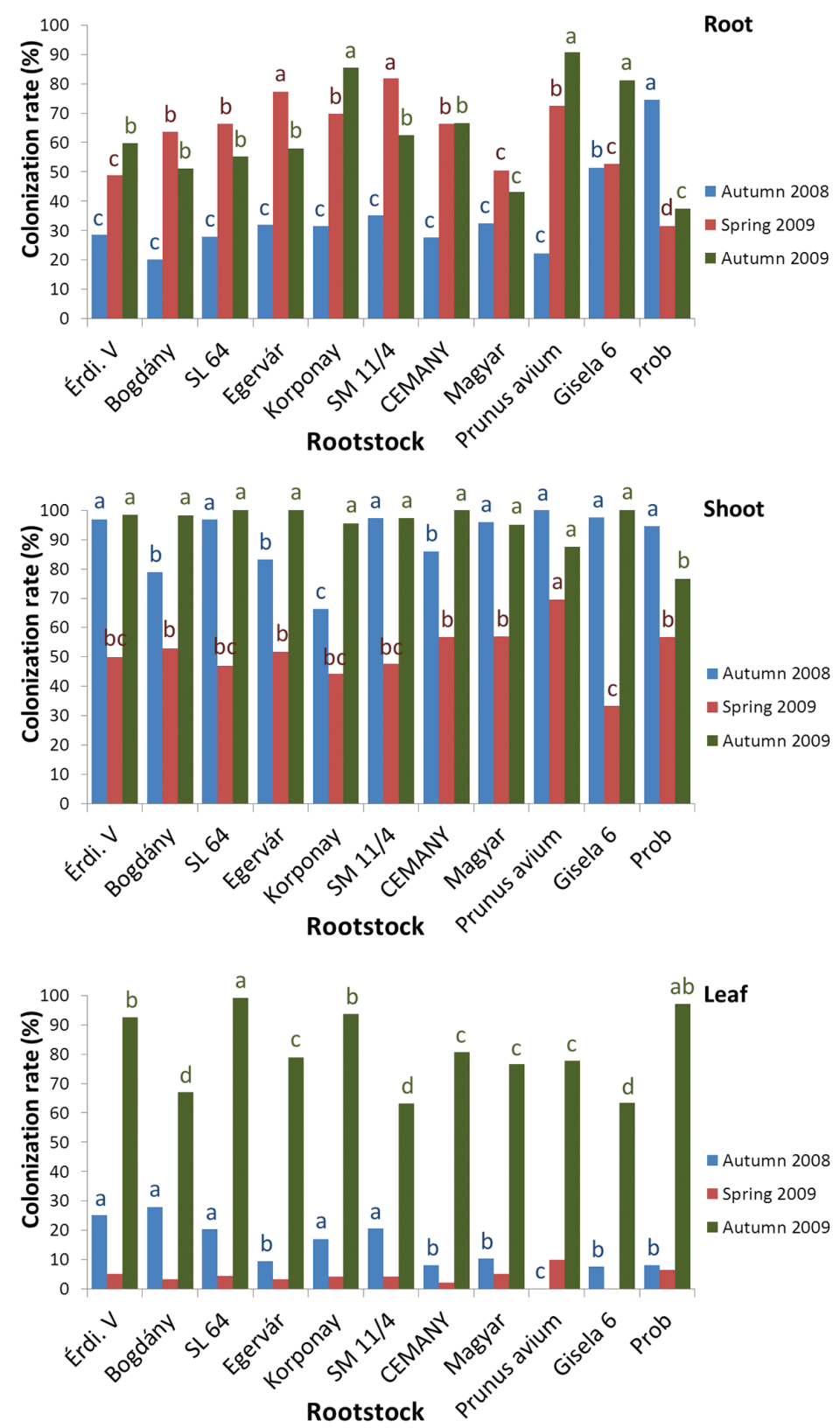

Fig. 1. Organ- and season-dependent changes of colonization of sweet cherry by endophytic fungi. The cultivar 'Petrus' was grafted on the rootstocks given on the $x$-axis. Samples were taken twice in autumn and once in spring from young shoots, roots and leaves. Colonies of cultivatable filamentous fungi grown on PDA medium were counted to calculate the colonization rates. On average, highest colonization rates

were observed in shoots, followed by roots, while colonization was extremely variable in leaves 
Table 1

Diversity of endophytic fungi in different organs of cherry grafts

\begin{tabular}{|c|c|c|c|c|c|c|c|c|}
\hline \multirow{2}{*}{ Order } & \multirow{2}{*}{ Genus/Species } & \multirow{2}{*}{$\begin{array}{l}\text { Best matching } \\
\text { sequence in } \\
\text { GenBank }\end{array}$} & \multirow{2}{*}{$\begin{array}{c}\text { Coverage } \\
\%\end{array}$} & \multirow{2}{*}{$\begin{array}{c}\text { Similarity } \\
\%\end{array}$} & \multicolumn{3}{|c|}{ Number of isolated colonies } & \multirow{2}{*}{ Total } \\
\hline & & & & & Root & Shoot & Leaf & \\
\hline Botryosphaeriales & Macrophomina & KF531825.1 & 100 & 99 & - & 88 & - & 88 \\
\hline Capnodiales & Davidiella & JF449792.1 & 98 & 99 & 323 & - & 16 & 339 \\
\hline Diaporthales & Phomopsis & EF432295.1 & 100 & 98 & - & 24 & - & 24 \\
\hline $\begin{array}{l}\text { Dothideomyc. } \\
\text { incertae sedis }\end{array}$ & Rhizopycnis & KF494166.1 & 99 & 99 & 15 & - & - & 15 \\
\hline Eurotiales & Aspergillus & KJ365316.1 & 100 & 100 & 17 & - & - & 17 \\
\hline Glomerellales & Glomerella & JX392857.1 & 100 & 99 & - & 21 & - & 21 \\
\hline Helotiales & Botrytis & СР009808.1 & 100 & 98 & - & 50 & - & 50 \\
\hline \multirow{8}{*}{ Hypocreales } & $\begin{array}{l}\text { Acremonium } \\
\text { sp. } 1\end{array}$ & HQ637291.1 & 100 & 99 & 15 & - & - & 15 \\
\hline & $\begin{array}{l}\text { Acremonium } \\
\text { sp. } 2\end{array}$ & JQ717326.1 & 100 & 99 & 133 & - & - & 133 \\
\hline & Fusarium sp.1 & KM817213.1 & 100 & 99 & 163 & 110 & - & 273 \\
\hline & Fusarium sp.2 & HQ607944.1 & 100 & 96 & 22 & 270 & - & 292 \\
\hline & Fusarium sp. 3 & JQ929907.1 & 100 & 99 & 44 & 23 & 252 & 319 \\
\hline & Fusarium sp.4 & LC055797.1 & 100 & 100 & 11 & - & - & 11 \\
\hline & Fusarium sp.5 & EU314982.1 & 99 & 99 & - & 59 & - & 59 \\
\hline & Neonectria & AJ875317.1 & 100 & 99 & 23 & - & - & 23 \\
\hline Pezizales & Pyronema & FN868474.1 & 99 & 99 & - & - & 10 & 10 \\
\hline \multirow{5}{*}{ Pleosporales } & Alternarii & KM215624.1 & 100 & 99 & \multirow{2}{*}{605} & \multirow{2}{*}{2173} & \multirow{2}{*}{626} & \multirow{2}{*}{3404} \\
\hline & fivermarta & KM274131.1 & 99 & 99 & & & & \\
\hline & Embellisia & JN859368.1 & 99 & 99 & 7 & 72 & - & 79 \\
\hline & Epicoccum & JX981489.1 & 100 & 99 & 28 & 404 & 110 & 542 \\
\hline & Paraphoma & JN903931.1 & 98 & 99 & 213 & - & - & 213 \\
\hline Sordariales & Chaetomium & KP101188.1 & 100 & 99 & - & 59 & - & 59 \\
\hline \multirow{2}{*}{ Xylariales } & Rosellinia & KF293984.1 & 79 & 98 & - & - & 50 & 50 \\
\hline & Xylaria & GU322456.1 & 99 & 99 & - & - & 13 & 13 \\
\hline \multirow{2}{*}{ Cantharellales } & $\begin{array}{l}\text { Ceratobasidium } \\
\text { sp.1 }\end{array}$ & KF176563.1 & 99 & 99 & 4 & - & - & 4 \\
\hline & $\begin{array}{l}\text { Ceratobasidium } \\
\text { sp. } 2\end{array}$ & KJ489319.1 & 100 & 98 & 15 & - & - & 15 \\
\hline Unknown & - & & & & 306 & 74 & 139 & 519 \\
\hline Total & & & & & 1944 & 3427 & 1216 & 6587 \\
\hline
\end{tabular}



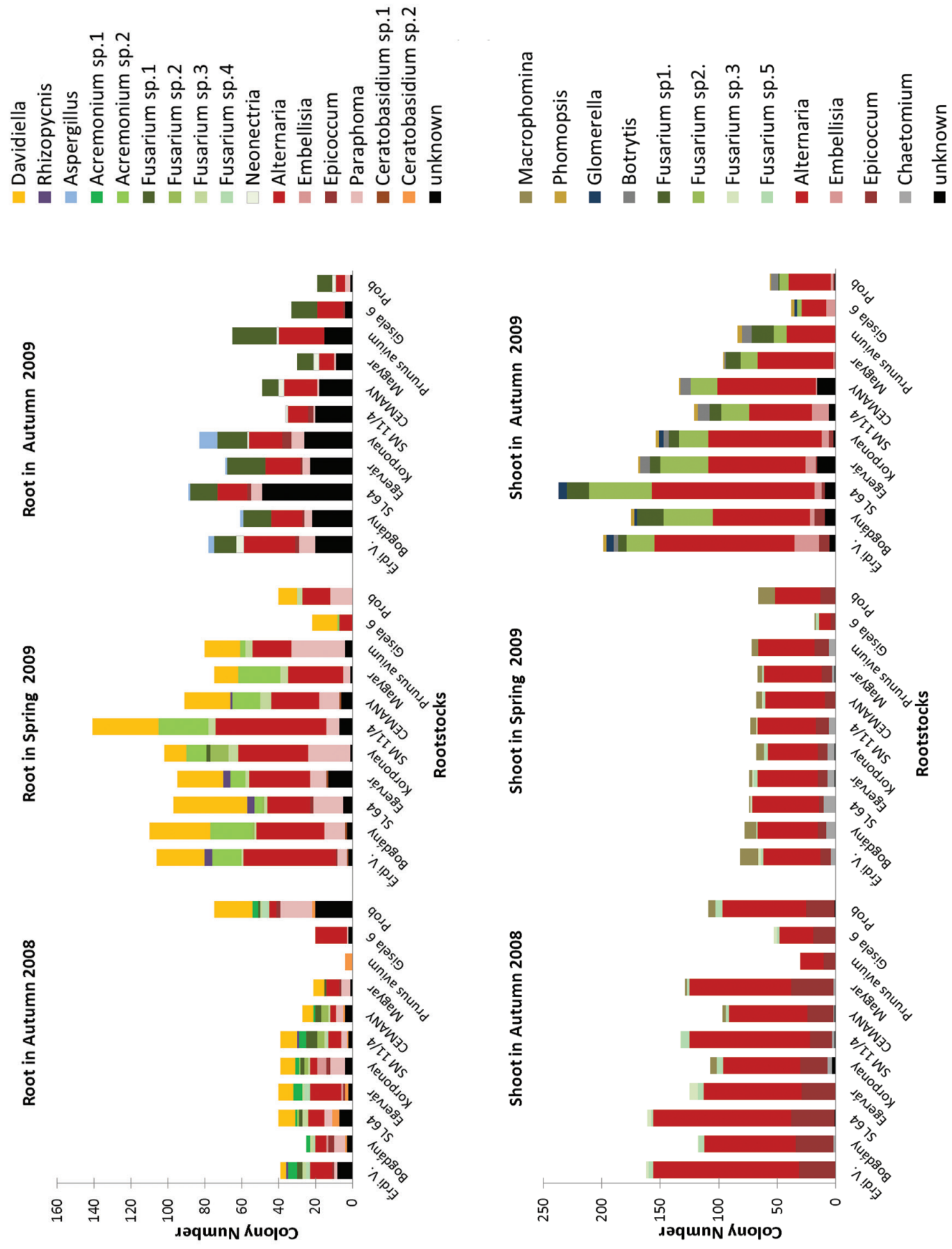

Acta Biologica Hungarica 67, 2016 


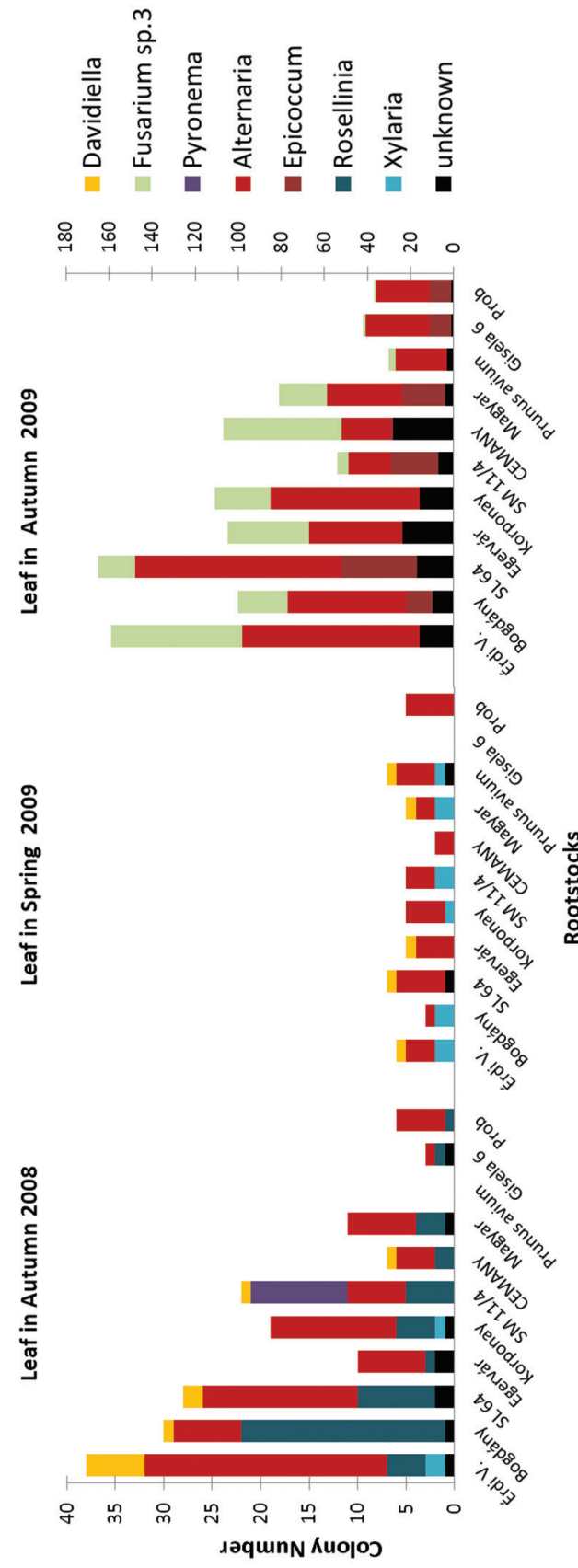

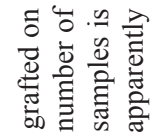

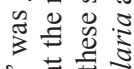

政

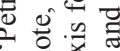

政

$\frac{\pi}{2}$

\%

政

के

足灵

年

등

.․․․․

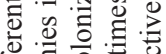

흥 잉

屯

की

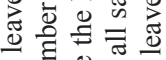

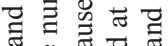

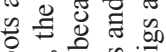

क 或 胥

s. 항

응 추

. 응 ․ㅖ…

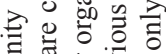

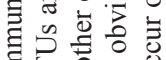

하의

ज

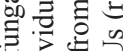

의명ㅇ

용

容

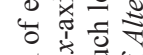

들 링

क्ष

을 है

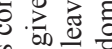

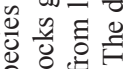

की

i

일을

Acta Biologica Hungarica 67, 2016 
plex pattern we could not answer this question unambiguously. However, pair-wise comparison in the $P$. mahaleb rootstock group showed significant differences in colonization rates in $16.7 \%$ of all pairs, while when any of the eight $P$. mahaleb rootstocks were compared to the other 3 rootstock species, $22.2 \%$ of pairs differed significantly (results not shown). As expected, highest similarity was observed when data for roots in the $P$. mahaleb group were compared. $P$. avium behaved like the P. mahaleb rootstocks, but GiSelA6 and Prob were different.

\section{Identification and distribution of endophytic fungi}

Fungal isolates were morphotyped and representative members of the groups were molecularly identified on the basis of their ITS sequences. An overview of the identified taxa is presented in Table 1, their distribution in different rootstock-scion combinations is shown in Fig. 2.

Twenty-six isolates were identified at least down to the genus level. The dominant genus, comprising more than $50 \%$ of all isolates, was Alternaria, followed by different Fusarium species and Epicoccum sp.. In case of Alternaria, two ITS sequences, consequently differing in just one nucleotide were found. We therefore believe that at least two operational taxonomic units (OTUs), Alternaria sp. 1 and sp. 2 were present, more or less evenly distributed in all organs investigated. Since we could not differentiate unequivocally between these OTUs by morphotyping, in our further analysis we treated them as one OTU. Examples for taxa showing exclusive or dominant association with roots are Paraphoma sp. which occurred only, and Davidiella mainly in this organ, while Macrophomina and Xylaria were detected only in shoots and leaves, respectively. Alternaria sp.1, Davidiella sp., Paraphoma sp., Acremonium sp. and Fusarium sp.1, were frequently isolated from root samples in all seasons. The highest number of identified taxa was found in roots (16 taxa), closely followed by shoots (13 taxa). Despite the high colonization rates in the second autumn only 8 taxa were detected in leaves (Table 2). Alternaria spp. was dominant in leaves in most combinations, followed by Rosellinia, Xylaria and Fusarium spp. in autumn 2008, spring 2009 and autumn 2009, respectively (Fig. 2).

To identify possible statistically significant differences between rootstocks and/or organs we calculated three commonly used species diversity indexes [the ShannonWeaver's (e_H'), the Simpson's (1-D) and the Species Richness (S) Index] by two-way ANOVA model to describe the eleven rootstocks and the three tissue types (Table 2). When using the Shannon-Weaver index no significant differences were detected between rootstocks and between tissue types $(F(10 ; 20)=0.4, p=0.9$; $\mathrm{F}(2 ; 20)=2.52, \mathrm{p}=0.1)$. Tukey's post hoc test, however, revealed a slight difference in Shannon-Weaver indices between leaves and the other two tissue types $(\mathrm{p}<0.1)$. In case of the Simpson index, significant differences were found between tissue types $(\mathrm{F}(2 ; 20)=8.9, \mathrm{p}<0.01)$, but not between rootstocks $(\mathrm{F}(10 ; 20)=0.4, \mathrm{p}=0.9)$. According to Tukey's post hoc test, the values measured in leaves and the other two tissue types were significantly different $(\mathrm{p}<0.05)$. Significant differences were also 
Table 2

Rootstock- and organ-dependent distribution of endophytic fungal species

\begin{tabular}{|l|c|c|c|c|c|c|c|c|c|}
\hline & \multicolumn{3}{|c|}{$\begin{array}{c}\text { Shannon-Weaver index } \\
\text { e }\end{array}$} & \multicolumn{3}{c|}{$\begin{array}{c}\text { Simpson index } \\
\text { 1-D }\end{array}$} & \multicolumn{3}{c|}{ Species richness } \\
\hline Rootstock & Root & Leaf & Shoot & Root & Leaf & Shoot & Root & Leaf & Shoot \\
\hline Érdi V & 0.74 & 0.73 & 0.68 & 0.59 & 0.63 & 0.60 & 15 & 6 & 13 \\
Bogdány & 0.70 & 0.77 & 0.72 & 0.55 & 0.59 & 0.56 & 14 & 7 & 12 \\
SL64 & 0.79 & 0.74 & 0.68 & 0.52 & 0.65 & 0.59 & 13 & 6 & 11 \\
Egervár & 0.69 & 0.67 & 0.72 & 0.60 & 0.67 & 0.58 & 14 & 5 & 12 \\
Korponay & 0.83 & 0.69 & 0.73 & 0.53 & 0.69 & 0.58 & 13 & 5 & 12 \\
SM 11/4 & 0.70 & 0.85 & 0.70 & 0.59 & 0.52 & 0.63 & 14 & 8 & 12 \\
CEMANY & 0.76 & 0.57 & 0.64 & 0.53 & 0.74 & 0.61 & 13 & 6 & 11 \\
Magyar & 0.84 & 0.78 & 0.64 & 0.53 & 0.56 & 0.62 & 8 & 7 & 11 \\
P. avium & 0.79 & 0.57 & 0.82 & 0.54 & 0.81 & 0.56 & 8 & 5 & 9 \\
GiSelA6 & 0.79 & 0.53 & 0.77 & 0.53 & 0.80 & 0.56 & 7 & 5 & 10 \\
Prob & 0.79 & 0.72 & 0.67 & 0.55 & 0.66 & 0.63 & 11 & 5 & 9 \\
\hline
\end{tabular}

found in species richness both between tissue types $(\mathrm{F}(2 ; 20)=51.6, \mathrm{p}<0.001)$ and between rootstocks $(\mathrm{F}(10 ; 20)=2.9, \mathrm{p}<0.05)$. Tukey's post hoc test indicated significant difference between S-values of leaves and the other two tissue types $(\mathrm{p}<0.05)$. It also detected significant differences between Gisela (a) together with P. avium (a) and Érdi (b) together with SM11/4 (b). All the other rootstocks were not significantly different from any other rootstocks $(a b)$.

\section{Growth retardation of Monilinia laxa by endophytic fungi}

The roles of endophytic fungi and their physiological effects on the host plants range from mutualistic, protective action to pathogenic potential [31, 19]. It has been suggested that endophytic fungi confer resistance to plant pathogens by direct and/or indirect inhibition of pathogenic microorganisms and by ecological effects [27, 45]. A common method to evaluate antagonistic activity of endophytic fungi against plant pathogens is the in vitro dual culturing [7]. We applied this method to find out whether any of our isolates are able to inhibit growth of M. laxa, the economically most important fungal pathogen of sweet cherry. Since M. laxa is a fast growing pathogen, we first performed a pilot experiment and selected endophyte isolates showing comparably vigorous growth in vitro as well as inhibiting activity. Seven endophytic species, Rhyzopycnis, Epicoccum, Alternaria sp.2, Fusarium sp.4, Embellisia, Ceratobasiudium sp.1 and Botrytis were chosen and grown in dual cultures with M. laxa. Horizontal growth was measured every day, and the average of daily growth was calculated for days 2-7 and 9-14, respectively. During this period of time $M$. laxa exhibited a constant daily growth rate. As shown in Fig. 3, all investigated endophytic fungi inhibited the growth of the pathogen, although the extent of inhibition was different. 


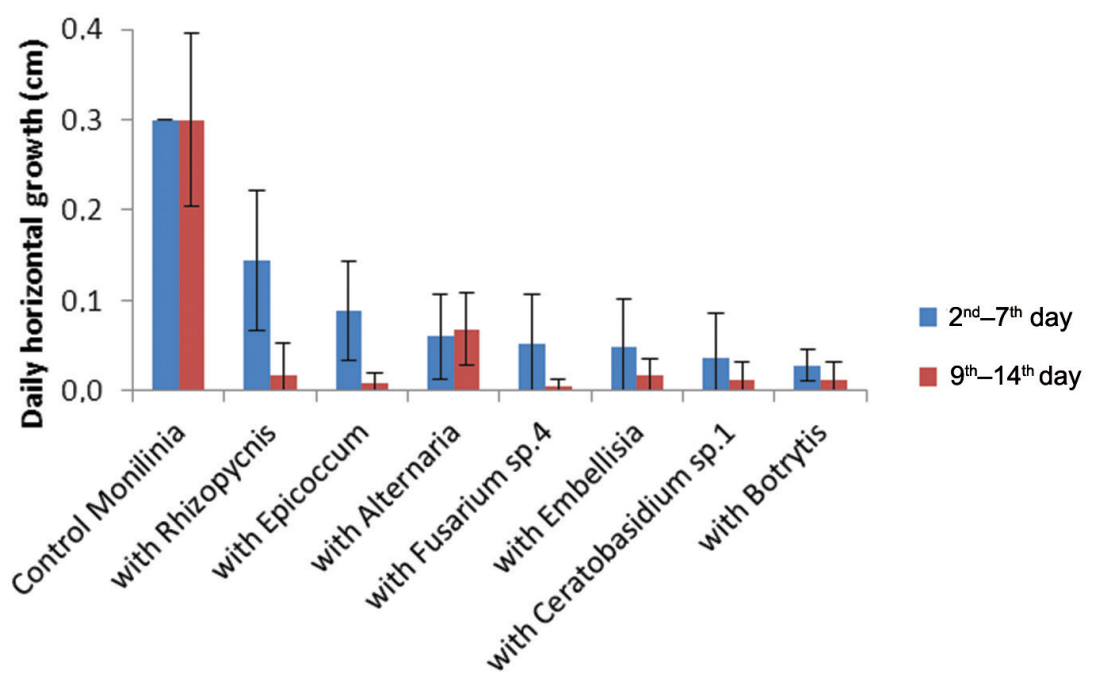

Fig. 3. Growth retardation of Monilinia laxa in dual culture with selected endophytic fungal isolates. To determine growth retardation M. laxa and one of the endophytes isolated in our experiments (given below the $x$-axis) were inoculated in a petri dish and were grown on PDA medium. Growth of M. laxa was measured between days 2-7 and 9-14. All endophytic fungi included in the test inhibited the growth of the pathogen in vitro

\section{DISCUSSION}

In this study we completed the first broad comparison of culturable endophytic fungal communities in different organs of sweet cherry under orchard conditions. Samples were collected in two consecutive years in spring and autumn from roots, shoots and leaves. In addition to seasonal or organ-dependent variation we also investigated whether the different rootstocks on which the sweet cherry cultivar 'Petrus' was grafted have measurable influence on abundance and diversity of endophyte populations under our conditions

In total we identified 26 fungal taxa, most of them belonging to the Pleosporales and Hypocreales order. Two Alternaria OTUs, Alternaria sp. 1 and Alternaria sp. 2 representing $51.7 \%$ of all isolates, dominated the populations, followed by five Fusarium OTUs (14.5\%) and by Epicoccum (8.2\%). Alternaria spp. have been described as the most common endophytes in several plants and were shown to inhibit different plant pathogens $[15,20,29,39]$. In our experiments two Alternaria OTUs were identified, but since only six selected colonies of the morphotyped isolates were subjected to ITS sequence analysis, further, more detailed analysis is needed to clarify how diverse these groups are. Fusarium is a serious plant pathogen, but many non-pathogenic endophytic Fusarium isolates have been reported in the literature [24]. E. nigrum has also been described as frequently occurring endophyte, 
mostly detected in phylloplane environment that is in good agreement with our findings in sweet cherry (see Table $1 ;[11,28]$ ).

While Alternaria, Fusarium and Epicoccum were detected in roots, shoots and leaves, the presence of several other endophytes seems to be organ specific. The major, apparently root-specific fungi were Acremonium, Davidiella and Paraphoma. Acremonium root endophytes were shown earlier to reduce disease incidence and severity of root-rots and soil-borne wilt diseases and nematode reproduction in several plants [16]. Davidiella sp., the telomorph of Cladosporium, is cosmopolitan and has been found in association with different substrata and as an endophyte of plants in temperate and antarctic regions [35, 38]. Some Cladosporium species are used as biocontrol agents and were also shown to stimulate growth and root development [30]. As observed in our experiments in sweet cherry, Cladosporium is not exclusively localized in roots, but occurs in leaves as well. Paraphoma sp. was also shown to promote plant growth and to play a role in protection against heavy metal stress [44].

Like in roots, we also observed twig- and leaf-specific association of endophytic fungi in sweet cherry. In shoots Macrophomina and Chetomium were found frequently, without any sign of disease symptoms (Table 1). M. phaseolina is known as a global devastating necrotrophic fungal pathogen causing charcoal rot disease and infecting more than 500 plant hosts, including major food crops [40]. Rosellinia, Xylaria (both Xylariales order) and Pyronema (Pezizales order) were isolated exclusively from leaves of sweet cherry. Organ-specific association of endophytic fungi has been described for several plants in the literature (see review by Berg et al. [6]).

In addition to differences between organs, we also observed differences between sampling events. In spring, culturable fungi were detected in only about $5 \%$ of samples (Fig. 2), possibly resulting from the usage of fungicides to prevent monilinia infection. In autumn, colonization was generally higher in both years, but a roughly 4 -fold enhancement was observed in the second year. Working under natural conditions in a bearing orchard, environmental factors like weather conditions are to be expected to influence endophyte community structure [37]. However, we believe that orchard management also played a decisive role in the enhancement of colonization. In the first year, to fight a Blumeriella infection in the orchard, repeated fungicide treatment was applied, that possibly reduced the number of endophytic fungi in the phyllosphere. In the second year no such treatment was necessary. The use of fungicides is known to significantly reduce colonization of apples by endophytic fungi, while enhancing the endophytic bacterial population [42]. An additional factor in our experiments was the heading of sweet cherry trees in summer of the second year, i.e. the removal of the upper $1.5 \mathrm{~m}$ of the crown to allow hand-picking of the fruits in the following years. Both this massive intervention in the physiological state of the trees and the lack of fungicide treatments might have contributed to multitudinous fungal colonization of leaves. A small enhancement of colonization was also observed in shoots, but not in roots (Fig. 2). Interestingly, only the colonization rates were enhanced, the species richness of endophytic fungal population remained consist- 
ently lower than that of roots or shoots. The composition of the population, however, was altered, and mainly Fusarium and Epicoccum were prevalent besides the dominating Alternaria spp. in autumn 2009, while Davidiella, Rosellinia and Xylaria sp. which were present during the two previous sampling times, were not detected. Similar restructuring of endophytic communities was seen by Rajala et al. [32], who observed variations in community structure and ITS copy number, but not in species richness in leaves. Although further experiments are needed to decide whether heading, i.e. the removal of a large part of photosynthesizing tissue alone would support such strongly fungal colonization, we would like to mention that in birch forests defoliation by moth outbreaks has been shown to have a beneficial effect even on endophytic fungi of the rhizosphere [36].

Grafting is of great importance in horticulture, however, the effect of rootstocks on endophyte communities has not yet been analyzed systematically in the literature. According to our results, the fungal community structure pattern of the studied sweet cherry - rootstock combinations seems to be influenced by physiological attributes of the organ, temporal changes and by orchard management rather than by rootstockdependent genetic variation of the host. In general, endophytic fungi had colonized twigs more densely than other tissues, although the infection level in twigs had a slight decline during the second sampling period. The abundance of recovered colonies and the density of endophyte infection in the root were slightly lower than in twigs, but much higher than in leaves. To identify differences between rootstocks we compared the eleven rootstocks according to the Shannon-Weaver's (e_H'), the Simpson's (1-D) as well as the Species Richness (S) Index values (Table 2). Significant differences were found primarily between tissues, using all three indexes, and these differences where enhanced when applying Tukey's post-hoc test. Whereas we only observed differences between rootstocks $(\mathrm{F}(10 ; 20)=2.9, \mathrm{p}<0.05)$ in species richness index. Tukey's post-hoc test detected significant differences between Gisela (a) together with P. avium (a) and Érdi (b) together with SM11/4 (b). All the other rootstocks were not significantly different from any other rootstocks $(a b)$. Thus, if there is a rootstock effect on the community structure of culturable endophytic fungi in sweet cherry, it is not very strong and may be masked by other, more influential factors under natural orchard conditions.

Protection of a plant host against a pathogen, a herbivore or even against an abiotic stress by endophytes has been described [39]. In sweet cherries M. laxa is the most important fungal pathogen. In a pilot study we identified 7 isolates which inhibit the growth of M. laxa. in dual culture on PDA medium. These organisms are obvious candidates for future applications, provided that they are also able to inhibit pathogen growth in trees or fruits in vivo, and that they remain apathogenic.

So far, the pattern of fungal endophyte diversity and phylogenic characteristics of different taxa which constitute the structure of endophytic communities on sweet cherry trees, have not been documented. Results of the present study give the first overview of community structure and dynamics of culturable fungal endophytes under orchard conditions and indicate the influence of crop management. To provide a comprehensive insight into the elements which shape host-endophyte interaction in 
cherry trees, further investigations should be extended to the identification of nonculturable fungi by NGS and should be carried out under controlled environmental conditions as well.

\section{ACKNOWLEDGEMENTS}

This study was supported by grant TÁMOP 4.2.1./B-09-01/KRM. The authors thank Orsolya Symmons for valuable discussion on the manuscript.

\section{REFERENCES}

1. Alvarez-Loayza, P., White, Jr., J. F., Torres, M. S., Balslev, H., Kristiansen, T., Svenning, J. C., Gil, N. (2011) Light converts endosymbiotic fungus to pathogen, influencing seedling survival and nichespace filling of a common tropical tree, Iriartea deltoidea. PLoS One 6, e16386.

2. Arnold, A. E., Henk, D. A., Eells, R. L., Lutzoni, F., Vilgalys, R. (2007) Diversity and phylogenic affinities of foliar fungal endophytes in loblolly pine inferred by culturing and environmental PCR. Mycologia 99, 185-206.

3. Arnold, A. E., Lutzoni, F. (2007) Diversity and host range of foliar fungal endophytes: Are tropical leaves biodiversity hotspots? Ecology 88, 541-549.

4. Arnold, A. E., Maynard, Z., Gilbert, G. S. (2001) Fungal endophytes in dicotyledonous neotropical tress: patterns of abundance and diversity. Mycol. Res. 12, 1502-1507.

5. Baltruschat, H., Fodor, J., Harrach, B. D., Niemczyk, E., Barna, B., Gullner, G., Janeczko, A., Kogel, K. H., Schäfer, P., Schwarczinger, I., Zuccaro, A., Skoczowski, A. (2008) Salt tolerance of barley induced by the root endophyte Piriformospora indica is associated with a strong increase in antioxidants. New Phytol. 180, 501-510.

6. Berg, G., Rybakova, D., Grube, M., Köberl, M. (2015) The plant microbiome explored: implications for experimental botany. J. Exp. Bot. doi:10.1093/jxb/erv466

7. Campanile, G., Ruscelli, A., Luisi, N. (2007) Antagonistic activity of endophytic fungi towards Diplodia corticola assessed by in vitro and in planta tests. Eur. J. Plant Pathol. 117, 237-246.

8. Choi, Y. W., Hyde, K. D., Ho, W. H. (1999) Single spore isolations of fungi. Fungal Diversity 3, 29-38.

9. Doyle, J. J., Doyle, J. H. (1990) A rapid total DNA preparation procedure for fresh plant tissue. Focus $12,13-15$.

10. Elamo, P., Helander, M. L., Saloniemi, I., Neuvonen, S. (1999) Birch family and environmental conditions affect endophytic fungi in leaves. Oecologia 118, 151-156.

11. Fávaro, L. C. L., Sebastianes, F. L. S., Araújo, W. L. (2012) Epicoccum nigrum P16, a sugarcane endophyte, produces antifungal compounds and induces root growth. PLOS ONE 7: e36826.

12. Gange, A. C., Dey, S., Currie, A. F., Sutton, B. C. (2007) Site- and species-specific differences in endophyte occurrence in two herbaceous plants. J. Ecology 95, 614-622.

13. Gazis, R., Chaverri, P. (2010) Diversity of fungal endophytes in leaves and stems of wild rubber trees (Hevea brasiliensis) in Peru. Fungal Ecology 3, 240-254.

14. Gazis, R., Rehner, S., Chaverri, P. (2011) Species delimitation in fungal endophyte diversity studies and its implications in ecological and biogeographic inferences. Molecular Ecology 20, 3001-3013.

15. Granado, J., Thürig, B., Kieffer, E., Petrini, L., Fliessbach, A., Tamm, L., Weibel, F. P., Wyss, G. S (2008) Culturable fungi of stored 'Golden Delicious' apple fruits: A one-season comparison study of organic and integrated production systems in Switzerland. Microb. Ecol. 56, 720-732.

16. Grunewaldt-Stöcker, G., von Alten H. (2003) Plant health effects of Acremonium root endophytes compared to those of arbuscular mycorrhiza. In: Roots: I. Abe (ed.) The Dynamic Interface between Plants and the Earth Developments in Plant and Soil Sciences Vol. 101, pp. 445-454. 
17. Gyeviki, M., Hrotkó, K., Honfi, P. (2012) Comparison of leaf population of sweet cherry (Prunus avium L.) trees on different rootstocks. Scientia Horticulturae 141, 30-36.

18. Haddadderafshi, N., Halász, K., Pósa, T., Péter, G., Hrotkó, K., Gáspár, L., Lukács, N. (2011) Diversity of endophytic fungi isolated from cherry (Prunus avium). J. Horticulture Forestry Biotech. $15,1-6$.

19. Hardoim, P. R., van Overbeek, L. S., Berg, G., Pirttilä, A. M., Compant, S., Andrea Campisano A., Döring, M., Sessitsch,A. (2015) The hidden world within plants: Ecological and evolutionary considerations for defining functioning of microbial endophytes. Microbiol. Mol. Biol. Rev. 79, 293-320.

20. Hortová, B., Novotný, D. (2011) Endophytic fungi in branches of sour cherry trees: a preliminary study. Czech Mycol. 63, 77-82.

21. Hrotkó, K., Magyar, L., Borsos, G., Gyeviki, M. (2014) Rootstock Effect on Nutrient Concentration of Sweet Cherry Leaves. Plant Nutrition 37, 1395-1409.

22. Hrotkó, K., Magyar, L., Simon, G., Gyeviki, M. (2007) Development in intensive orchard systems of cherries in Hungary. Int. J. Hortic. Sci. 13, 79-86.

23. Juhász, Á., Sepsi, P., Nagy, Z., Tőkei, L., Hrotkó, K. (2013) Water consumption of sweet cherry trees estimated by sap flow measurement. Sci. Hortic. 164, 41-49.

24. Kuldau, G. A., Yates, I. E. (2000) Evidence for Fusarium endophytes in cultivated and wild plants. In: Microbial Endophytes, C. W. Bacon, J. F. White, Jr. (eds), Marcel Dekker Inc., New York, pp. 85-117.

25. Lamit, L. J., Lau, M. K., Schultz, C. M., Wooley, S. C., Whitham, T. G., Gehring, C. A. (2014) Tree genotype and genetically based growth traits structure twig endophyte communities. Am. J. Botany $11,464-478$.

26. Lehtonen, P. T., Helander, M., Siddiqui, S. A., Lehto, K., Saikkonen, K. (2006) Endophytic fungus decreases plant virus infections in meadow ryegrass (Lolium pretense). Biol. Lett. 2, 620-623.

27. Li, C.-J., Gao, J.-H., Nan, Z.-B. (2007) Interactions of Neotyphodium gansuense, Achnatherum inebrians, and plant-pathogenic fungi. Mycological Research 111, 1220-1227.

28. Martini, M., Musetti, R., Grisan, S., Polizzotto, R., Borselli, S., Pavan, F., Osler, R. (2009) DNAdependent detection of the grapevine fungal endophytes Aureobasidium pullulans and Epicoccum nigrum. Plant Disease 93, 993-998.

29. Pancher, M., Ceol, M., Corneo, P. E., Longa, C. M. O., Yousaf, S., Pertot, M., Campisano, A. (2012) Fungal endophytic communities in grapewines (Vitis vinifera L.) respond to crop management. Appl. Environ. Microbiol. 78, 4308-4317.

30. Paul, D., Park, K. S. (2013) Identification of volatiles produced by Cladosporium cladosporoides CL-1, a fungal biocontrol agent that promotes plant growth. Sensors 13, 13969-13977.

31. Rai, M., Agarkar, G. (2014) Plant-fungal interactions: What triggers the fungi to switch among lifestyles? Crit. Rev. Microbiol. 10, 1-11.

32. Rajala, T., Velmala, S. M., Haapanen, M., Müller, M., Pennanen, T. (2013) Endophyte communities vary in the needles of Norway spruce clones. Fungal Biol. 117, 182-190.

33. Rodriguez, R. J., Freeman, D. C., McArthur, E. D., Kim, Y. D., Regina, S. R. (2009b) Symbiotic regulation of plant growth, development and reproduction. Commun. Integr. Biol. 2, 141-143.

34. Rodriguez, R. J., White, Jr. J. E., Arnold, A. E., Redman, R. S. (2009a) Fungal endophytes: diversity and functional roles. New Phytologist 182, 314-330

35. Rosa, L. H., Almeida, Vieira, Mde L., Santiago, I. F., Rosa, C. A. (2010) Endophytic fungi community associated with the dicotyledonous plant Colobanthus quitensis (Kunth) Bartl. (Caryophyllaceae) in Antarctica. FEMS Microbiol Ecol. 73, 178-189.

36. Saravesi, K., Aikio, S., Väli, P. R., Routsalainen, A. L., Kaukonen, M., Huusko, K., Soukas, M., Brown, S. P., Jumpponen, A., Tuomi, J., Markkola, A. (2015) Moth outbreaks alter root-associated fungal communities in subarctic mountain birch forests. Microb. Ecol. 69, 788-797.

37. Saucedo-Garcia, A., Anaya, A. L., Espinisa-Garcia, F. J., González, M. C. (2014) Diversity and communities of foliar endophytic fungi from different agroecosystems of Coffea arabica $\mathrm{L}$. in two regions of Veracruz, Mexico. PLOS One 9: e98454.

38. Schubert, K., Groenewald, J. Z., Braun, U., Dijksterhuis, J., Starink, M., Hill, C. F., Zalar, P., Hoog, G. S., Crous, P. W. (2007) Biodiversity in the Cladosporium herbarum complex (Davidiellaceae, 
Capnodiales), with standardization of methods for Cladosporium taxonomy and diagnostics. Stud. Mycol. 58, 105-156.

39. Soltani, J., Moghaddam, M. S. (2014) Diverse and bioactive endophytic Aspergilli inhabit Cupressaceae plant family. Arch. Microbiol. 196, 635-644.

40. Su, G., Suh, S. O., Schneider, R. W., Russin, J. S. (2001) Host specialization in the charcoal rot fungus, Macrophomina phaseolina. Phytopathology 91, 120-126.

41. Sun, X., Guo, L. D., Hyde, K. D. (2011) Community composition of endophytic fungi in Acer truncatum and their role in decomposition. Fungal Diversity 47, 85-95.

42. Teixidó, N., Usall, J., Magan, N., Vinas, I. (2008) Microbial population dynamics on Golden Delicious apples from bud to harvest and effect of fungicide applications. Ann. Applied Biol. 134, 109-116.

43. White, T. J., Bruns, T., Lee, S., Taylor, J. W. (1990) Amplification and direct sequencing of fungal ribosomal RNA genes for phylogenetics. In: Innis, M. A., Gelfand, D. H., Sninsky, J. J., White, T. J. (editors) PCR Protocols: A Guide to Methods and Applications. New York: Academic Press Inc; pp. 315-322.

44. Zhang, H. H., Tang, M., Chen, H., Wang, Y. J. (2012) Effects of a dark-septate endophytic isolate LBF-2 on the medicinal plant Lycium barbarum L. J. Microbiol. 50, 91-96.

45. Zhi-Lin, Y., Yi-Cun, C., Bai-Ge, X., Chu-Long, Z. (2012) Current perspectives on the volatile-producing fungal endophytes. Crit. Rev. Biotech. 32, 363-373.

46. Zimmerman, N. B., Vitousek, P. M. (2012) Fungal endophyte communities reflect environmental structuring across a Hawaiian landscape. Proc. Natl. Acad. Sci. 109, 13022-13027. 